\title{
PRESENT BIODIVERSITY STATUS OF LOACHES IN THE SELECTED HILL-STREAMS OF BANGLADESH
}

\section{Md. Kamrul Hasan Akand, Mostafa Ali Reza Hossain* and Md. Shariful Islam}

Department of Fisheries Biology and Genetics, Faculty of Fisheries, Bangladesh Agricultural University, Mymensingh-2202, Bangladesh

*Corresponding author: Mostafa Ali Reza Hossain, E-mail: marhossain@bau.edu.bd

\begin{tabular}{|c|c|}
\hline ARTICLE INFO & ABSTRACT \\
\hline Received & A year-long survey was conducted to study the biodiversity status of freshwater loaches of \\
\hline 20.0 & $\begin{array}{l}\text { Bangladesh. Data and sample collection were carried out in the hill-streams of Bangladesh in } \\
\text { the three districts namely Sylhet, Netrokona and Dinajpur. Fish samples were also collected }\end{array}$ \\
\hline Accepted & from Mymensingh district. The study was based on fish landing centre and fish market visit, on \\
\hline 31.08 .2015 & $\begin{array}{l}\text { the spot data collection, interview of the fishermen and the fish traders, sample collection and } \\
\text { secondary data collection. During the study, } 12 \text { loaches under } 2 \text { families were found. Among }\end{array}$ \\
\hline Online & the collected loaches 8 are exclusively used as food fish and the rest 4 species can be \\
\hline 04.09 .2015 & $\begin{array}{l}\text { considered as both food fish and ornamental fish. Among the total number of species found } \\
\text { during the study, } 2 \text { loaches were threatened based on IUCN Red List. Among the loaches }\end{array}$ \\
\hline Key words & recorded in the survey, 2 are endangered (EN), 3 data deficient (DD) and 7 not threatened \\
\hline Freshwater loach & (NO). Among the collected loaches Botia dario, Botia lohachata and Lepidocephalichthys \\
\hline Biodiversity status & annandalei were very rare. The non-availability and less availability of some of the species \\
\hline & indicate the alarming decline of the biodiversity of loaches in the surveyed area and in the \\
\hline Bangladesh & untry as a whole. \\
\hline
\end{tabular}

To cite this article: MKH Akand, MAR Hossain and MS Islam, 2015. Present biodiversity status of loaches in the selected hill-streams of Bangladesh. Res. Agric. Livest. Fish. 2 (2): 329-334.

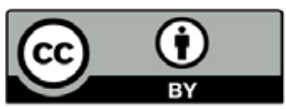

This is an open access article licensed under the terms of the Creative Commons Attribution 4.0 International License

www.agroaid-bd.org/ralf, E-mail: editor.ralf@gmail.com 


\section{INTRODUCTION}

Bangladesh is very rich in aquatic biodiversity. The significance of the aquatic biodiversity of Bangladesh is recognized by its high productivity and ability to support highly human populated country like Bangladesh. This country is blessed with an abundance of inland water bodies filled with a diverse aquatic species. According to the World Bank (1991), Bangladesh has the water resources (river, floodplains, ponds, beels, haors and a long coastline), diverse aquatic wealth and climate suitable for high yields and considerable increase in fish production. The mainstay of Bangladesh's economy is agriculture and one of the major sectors of Bangladesh agriculture is represented by the fisheries sector.

Loaches are one of the major groups in the freshwater fish fauna of Bangladesh. Loaches in Bangladesh are represented by 9 genera. Their general body pattern is oblong, elongate, compressed or cylindrical but not depressed. Snout and lips are fleshy. Small inferior mouth is thick and six to eight pendulous barbells are present. The fishes are usually scale less; scales when present, small and cycloid. A suborbital or pre-orbital spine is present or absent. Lateral line is nearly straight. Vertical fins are spineless. Dorsal fin is with varying number of rays (8-30), anal with few (7-8) rays. Pelvic are present or absent. Most of them are of small size, inhabiting the hill streams, a few are also found in rivers and swamps. Some of them are very colorful and are reared in aquarium. The fishes are eaten by people. The members of this group protect themselves from danger through hiding with great rapidity in the sand, gravel or underneath rocks and boulders in swift flowing, clear, cool streams where they abound. They hide underneath rocks and boulders and in sands to avoid being swept away by strong current.

Hossain et al. (2012) listed 293 species of freshwater fishes under 13 orders and 61 families from Bangladesh. Among the 61 families of freshwater fish, loach is the most important fish group in Bangladesh. At least 25 species of loaches belonging to 9 genera and 3 families have been recorded so far in Bangladesh. Generally they grow with natural care. These fishes are important due to food and ornamental value.

Biodiversity of loaches is decreasing day by day. Biodiversity of loaches are poorly exploited in Bangladesh. During last ten years no work was done to study the biodiversity status of loaches in Bangladesh.

\section{MATERIALS AND METHODS}

The present study was carried out with a view to collecting and preserving available freshwater loaches of Bangladesh and identifies them up to species level by studying their taxonomic and morphological characteristics. Another objective of the study was to evaluate biodiversity status and distribution of loaches.

\section{Study sites}

This study was carried out for a period of 10 months from September 2013 to July 2014 in the selected hillstreams of Bangladesh. Data and sample collection were carried out mainly in the selected hill streams of Bangladesh comprising the three districts namely Sylhet, Netrakona and Dinajpur. Fish samples were also collected from Mymensingh district (Figure 1).

Frequent visits were carried out to the selected areas and samples of loaches were collected from these areas. Sample collection was made mainly from the fishermen fishing in the rivers and other natural water bodies, from fish-landing centers and fish markets.

\section{Species identification}

The specimens thus collected during the field visit were identified primarily in the field. Those, which appeared difficult to identify, were marked properly. All the identified and unidentified fish samples were preserved with $10 \%$ formalin in the plastic jars and transported to the laboratory of the Department of Fisheries Biology and Genetics at Bangladesh Agricultural University, Mymensingh for further study. Primary data of concerned species were made from the fishermen, fish traders, and local people and also from the spot situation. Local name of the collected fish samples, source, distribution and availability of the species etc. were also collected from the study sites. 


\section{Secondary data collection}

Secondary data were collected from the District Fisheries Offices, Bangladesh Fisheries Research Institute (BFRI) and Department of Fisheries (DoF). Research papers on the freshwater fish fauna of Bangladesh were also consulted towards compiling the past data of abundance and availability for assessing biodiversity status.

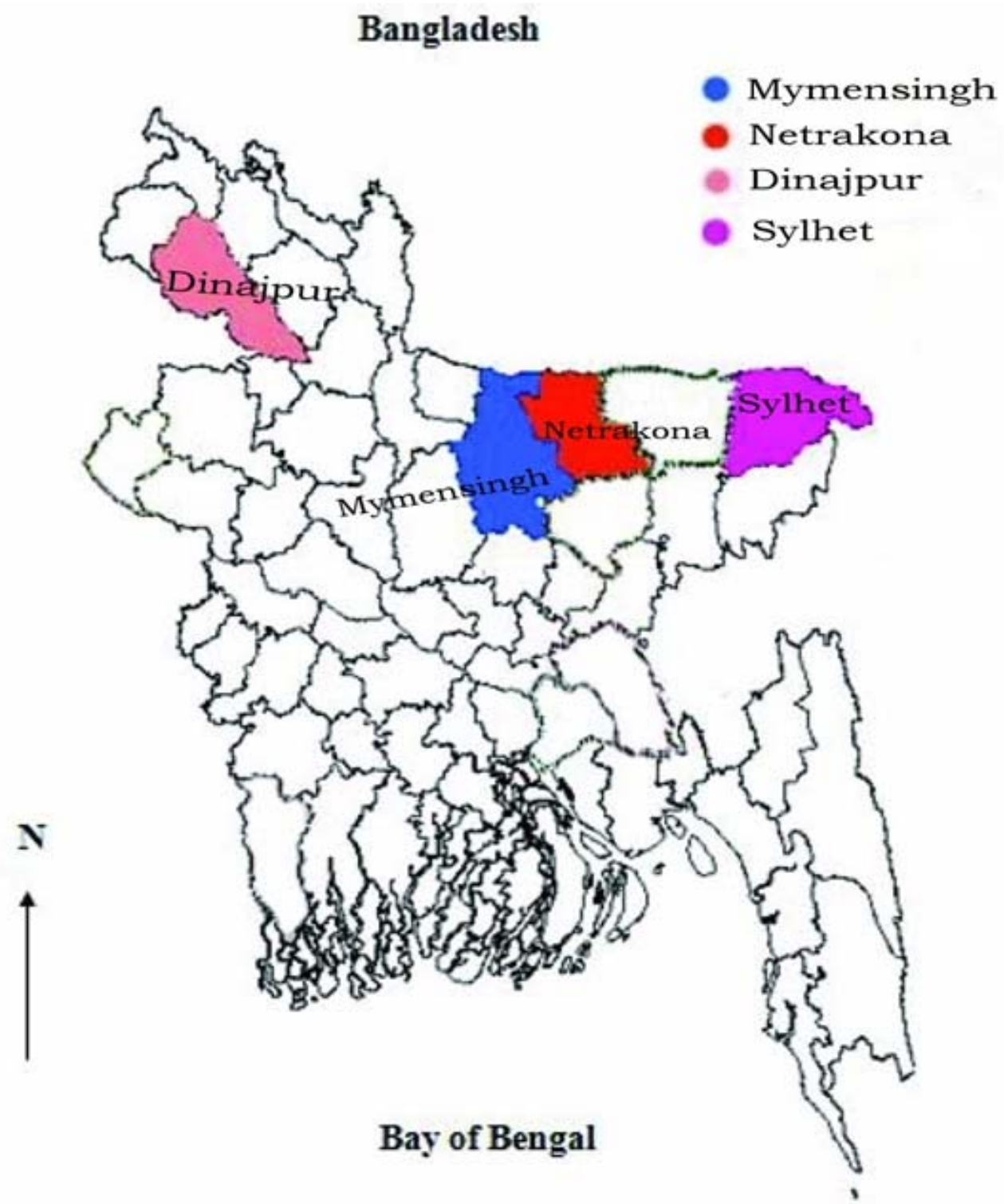

Figure 1. Map showing the study sites from where loaches are collected 


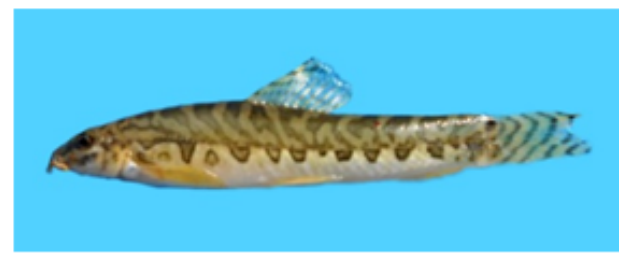

Acanthocobitis botia

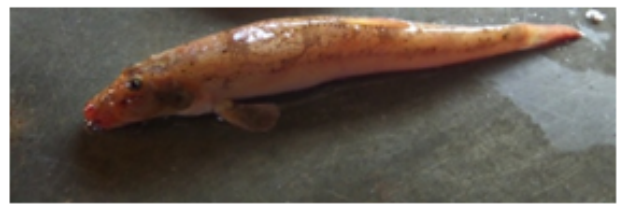

Canthophrys gongota

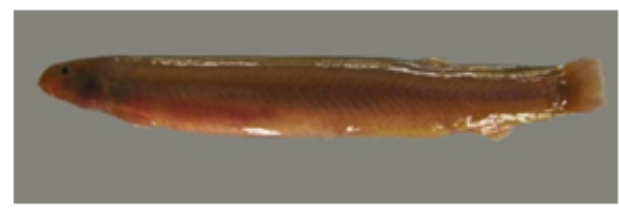

Pangio pangia

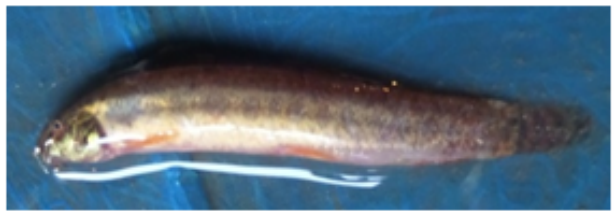

Lepidocephalichthys irrorata

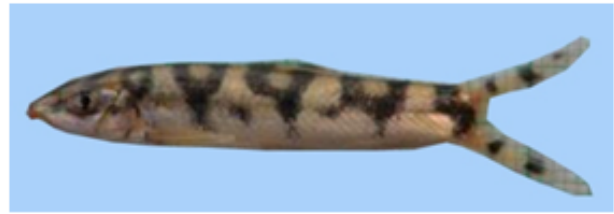

Botia lohachata

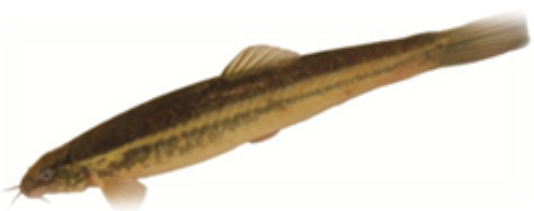

Lepidocephalichthys berdmorei

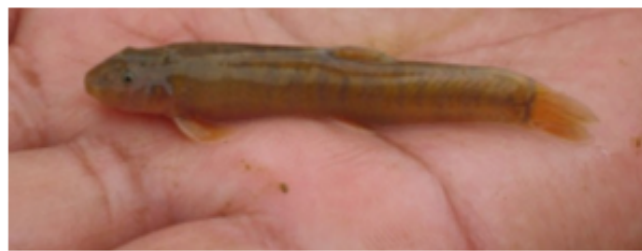

Schistura sikmaiensis

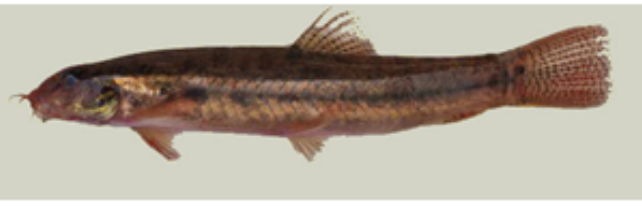

Lepidocephalichthys annandalei

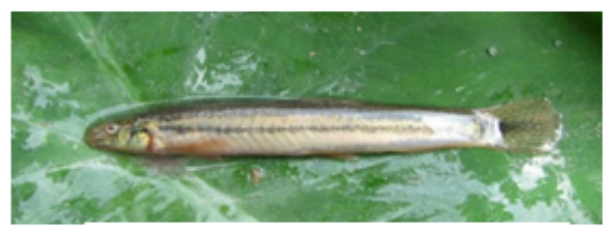

Lepidocephalichthys guntea

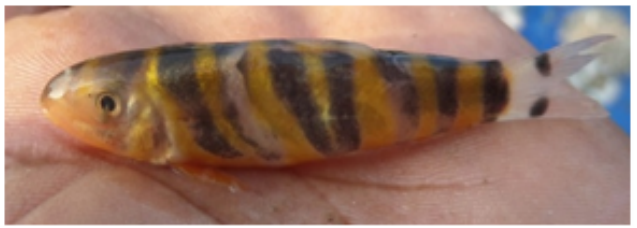

Botia dario

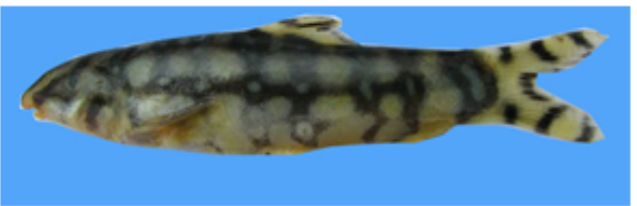

Botia dayi

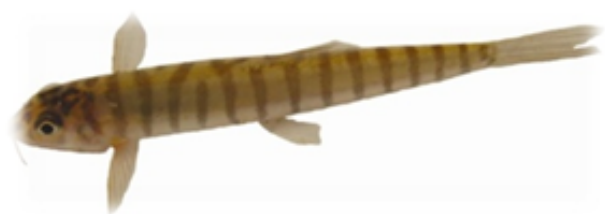

Schistura scaturigina

Figure 2. The photos with their scientific names of the loaches found in the present study 


\section{RESULTS AND DISCUSSION}

\section{Species diversity}

Among 25 species, a total of 12 species of freshwater loaches were recorded, identified and preserved during the study period under 2 families. The families are: Cobitidae and Balitoridae. List of loaches observed during the present study with their biodiversity status are given in Table 1. Hasan et al. (2013) found a total of 16 loaches. While Ahmed etal. (2013) reported 11 species of loach in the hill-streams of Bangladesh. Another author Galib et al. (2013) reported 4 species of loach while he surveying biodiversity status on the River Chhoto Jamuna.

In fact, how many loaches we have in Bangladesh is a controversial issue. Actually no countrywide survey has been conducted ever before and there is no proper collection of preserved loaches in Bangladesh. That is why no proper taxonomic identification of all the freshwater loaches has been made. Hossain et al. (2012) listed 25 species of loaches belonging to 9 genera under 3 families. There are 12 and 9 reported loach species in Bangladesh of the family Cobitidae and Balitoridae, respectively. In the present study, the numbers of observed loaches were 9 and 3 under the family Cobitidae and Balitoridae, respectively (Figure 2).

Table 1. List of freshwater loaches observed in the present study with their biodiversity status

\begin{tabular}{lllll}
\hline SI. No. & Species & $\begin{array}{l}\text { Local } \\
\text { name }\end{array}$ & $\begin{array}{l}\text { Biodiversity } \\
\text { Status } \\
\text { (IUCN, 2000) }\end{array}$ & Fish value \\
\hline Cobitidae & & & \\
\hline 1 & Botiadario & Bou, Rani & EN & Ornamental/Food fish \\
2 & Botiadayi & Rani & DD & Ornamental/Food fish \\
3 & Botialohachata & Putul & EN & Ornamental/Food fish \\
4 & Lepidocephalichthysguntea & Gutum & NO & Food fish \\
5 & Lepidocephalichthysannandalei & Gutum & NO & Food fish \\
6 & Lepidocephalichthysirrorata & Puiya & DD & Food fish \\
7 & Lepidocephalichthysberdmorei & Puiya & DD & Food fish \\
8 & Pangiopangia & Panga & NO & Food fish \\
9 & Canthophrysgongota & Cheng & NO & Food fish \\
& & gutum & & \\
\hline Balitoridae & & & & Food fish \\
\hline 10 & Acanthocobitisbotia & Balichata & DD & Ornamental/Food fish \\
11 & Schisturasikmaiensis & - & DD & Food fish \\
\hline 12 & Schisturascaturigina & Dari & DD & \\
\hline
\end{tabular}

$\mathrm{EN}=$ Endangered, $\mathrm{DD}=$ Data Deficient, $\mathrm{NO}=$ Not Threatened

\section{Availability and distribution}

The availability and distribution of the loaches were recorded during the study period (Table 2). The result shows that most of the loaches are available in streams, rivers, beels, lakes, and also in swamps. Most of the species were abundant in streams and rivers. Loaches were more or less available round the year. However, all species were not available in all the seasons. Some species were more available in summer but not in winter whereas others were more available in winter but not in summer. Ahmad (1997) observed that seasonal fluctuation in the fish species is a normal phenomenon. There were also some species, which were found throughout the year. Abundance of fish in winter was comparatively higher than the rest of the year as the water level in freshwater bodies decreases or dries up in this season. Among the observed loach species Lepidocephalichthys guntea, Lepidocephalichthys irrorata, Canthophrys gongota, Acanthocobiti sbotia, and 
Schistura scaturigina were more available than others. Botia dario, Botia lohachata and Lepidocephalichthys annandalei were found during the study with very low abundance and hence considered as rare species.

Table 2. Species-wise availability of loaches in the selected hill- streams

\begin{tabular}{lllll}
\hline Species name & \multicolumn{3}{c}{ Observed in the study sites } \\
\cline { 2 - 5 } & Sylhet & Netrokona & Dinajpur & Mymensingh \\
\hline Botia dario & $\sqrt{y}$ & $\sqrt{ }$ & $\sqrt{ }$ & $\sqrt{ }$ \\
Botia lohachata & $\sqrt{ }$ & $\sqrt{ }$ & $\sqrt{ }$ & $\sqrt{ }$ \\
Botia dayi & $\sqrt{ }$ & $\sqrt{ }$ & $\sqrt{ }$ & $\sqrt{ }$ \\
Pangio pangia & $\sqrt{ }$ & $\sqrt{ }$ & $\sqrt{ }$ \\
Lepidocephalichthys guntea & $\sqrt{ }$ & $\sqrt{ }$ & $\sqrt{ }$ \\
Lepidocephalichthys annandalei & $\sqrt{ }$ & $\sqrt{ }$ & $\sqrt{ }$ \\
Lepidocephalichthy sirrorata & $\sqrt{ }$ & $\sqrt{ }$ & $\sqrt{ }$ \\
Lepidocephalichthys berdmorei & & & $\sqrt{ }$ & $\sqrt{ }$ \\
Canthophrys gongota & & & $\sqrt{ }$ \\
Acanthocobitis botia & & & $\sqrt{ }$ \\
Schistura scaturigina & & & & \\
Schistura sikmaiensis & & & & \\
\hline
\end{tabular}

\section{CONCLUSION}

Improvement of fish habitat is essential in this very moment to conserve the valuable fish species of our country. Strengthening and enforcing fishing law is also essential. Considering the importance and biodiversity values, quantitative and qualitative study on the availability of loaches and thorough and countrywide habitat study are undeniable. Therefore, in depth, long-term investigation is urgently needed not only for the conservation and rehabilitation but also for creating awareness among the policy makers to the government and non-government organizations, groups and general mass.

\section{REFERENCES}

1. Ahmad N 1997. Marketing of fish from selected floodplains in Bangladesh. In: Open water Fisheries of Bangladesh. The University Press Limited, Dhaka- 1000, 72 pp.

2. Ahmed ATA, Rahman MM, Mandal S 2013. Biodiversity of hill-stream fishes in Bangladesh. Zootaxa, 3700: 283-292.

3. Froese R and D Pauly, 2014. List of freshwater fishes in Bangladesh.

4. Galib SM, Naser SMA, Mohsin ABM, Chaki N and HF Fahad, 2013. Fish diversity of the River ChotoJamuna, Bangladesh-Present status and conservation needs. International Journal of Biodiversity and Conservation 5: 389-395.

5. Hasan MR, Kabir MR, Miah MMA and Hossain MAR 2013: Present biodiversity status of freshwater loaches of Bangladesh. Bangladesh Research Publications Journal 8: 203-214.

6. Hossain MAR, Wahab MA and Belton B 2012: The Checklist of the Riverine Fishes of Bangladesh. FAN-Bangladesh 2: 29-39.

7. IUCN (International Union for Conservation of Nature) 2000: Red of Threatened Fishes of Bangladesh. Islam MA, Ameen M and Nishat A (Editors). The World Conservation Union, Dhaka, Bangladesh.

8. WB (World Bank) 1991: Bangladesh fisheries Sector Review, Report No. 8830-BD, Dhaka, 120 pp. 